\title{
ANALISIS KOHESI DAN KOHERENSI PADA TEKS CERPEN, TEKS PROSEDUR, TEKS LINGKUNGAN DAN KEMUNGKINAN PEMBELAJARAN DI SEKOLAH
}

diajukan untuk memenuhi tugas akhir perkuliahan Analisis Wacana Bahasa Indonesia yang diampu oleh Prof. Dr. Syahrul Ramadhan, M.Pd

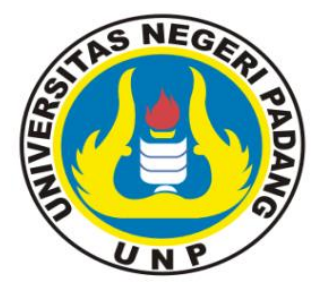

1. ANISA APRILIA

NIM 17016003/2017

PROGRAM STUDI PENDIDIKAN BAHASA INDONESIA

FAKULTAS BAHASA DAN SENI

UNIVERSITAS NEGERI PADANG

2019 


\section{KATA PENGANTAR}

Puji syukur atas kehadirat Allah SWT yang telah melimpahkan rahmat dan hidayah-Nya sehingga penulis dapat menyelesaikan makalah dengan judul "Analisis Kohesi dan Koherensi pada Teks Cerpen, Teks Prosedur, Teks Lingkungan dan Kemungkinan Pembelajaran di Sekolah" dengan baik meskipun banyak terdapat kekurangan didalamnya. Penulis ucapkan terima kasih kepada Prof. Dr. Syahrul Ramadhan, M.Pd. selaku dosen mata kuliah Wacana Bahasa Indonesia yang telah membimbing penulis dalam menyelesaikan makalah ini.

Penulis berharap makalah ini berguna bagi pembaca dan penulis sendiri untuk menambah wawasan serta pengetahuan mengenai analisis kohesi dan koherensi pada teks cerpen, teks prosedur, teks lingkungan dan kemungkinan pembelajaran di sekolah. Penulis sangat menyadari makalah ini memiliki banyak kekurangan dan jauh dari kata sempurna. Oleh sebab itu, kritikan dan saran dari pembaca sangat penulis harapkan.

Padang, Juni 2020

Anisa Aprilia 


\section{DAFTAR ISI}

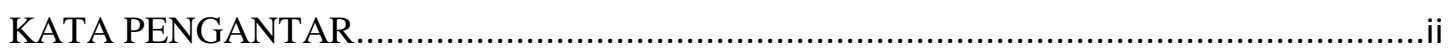

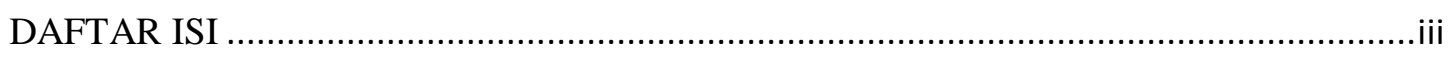

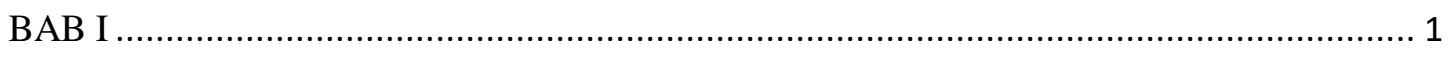

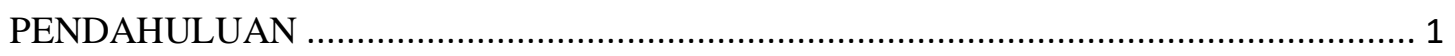

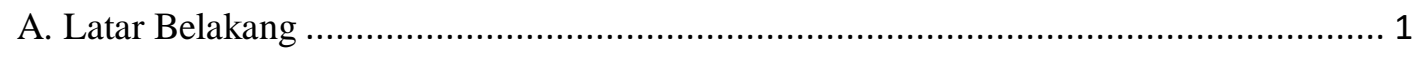

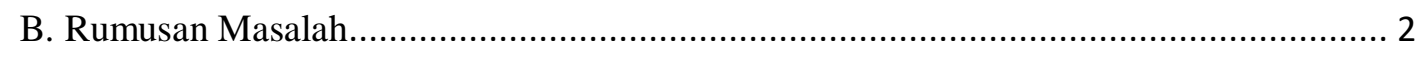

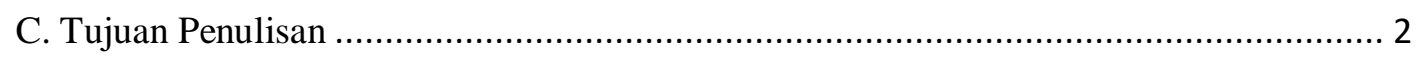

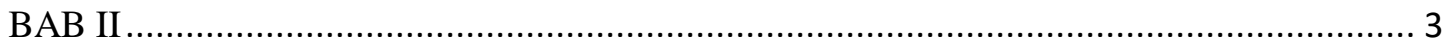

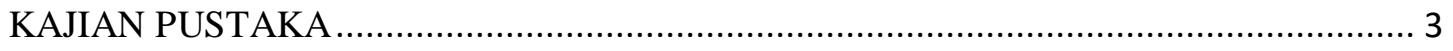

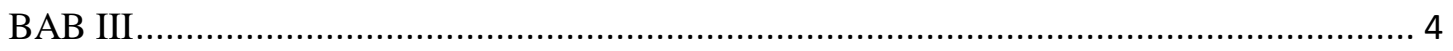

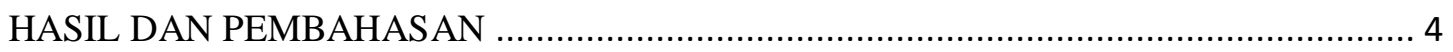

A. Analisis Teks Cerpen "Si Bangkak” Karya A.A Navis berdasarkan Kohesi dan

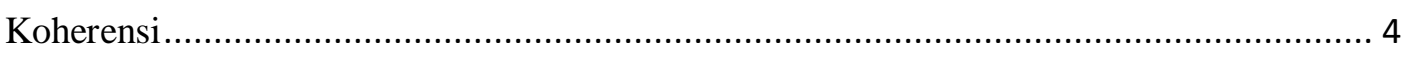

B. Analisis Teks Prosedur “Cara Memasak Mie Goreng Instan” berdasarkan Kohesi dan

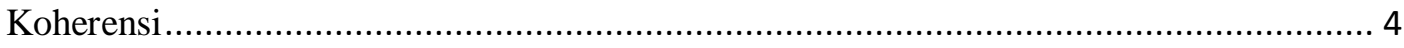

C. Analisis Teks Wacana Lingkungan "Sampah Rumah Tangga” berdasarkan Kohesi dan

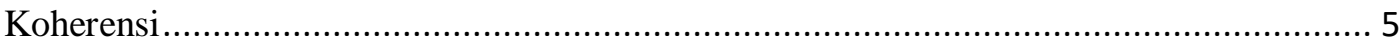

D. Deskripsi Kemungkinan Pembelajaran Ketiga Wacana Tersebut di Sekolah ................. 6

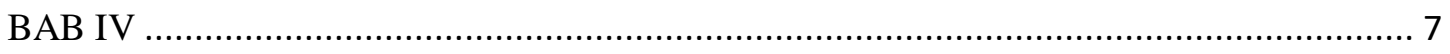

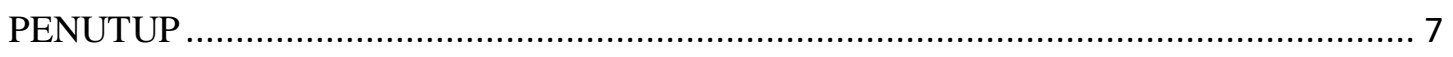

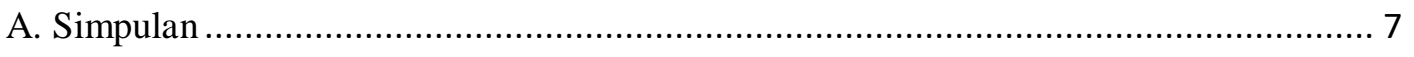

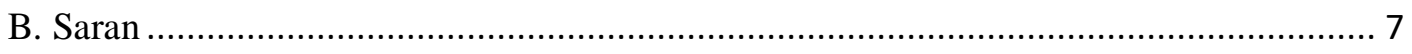

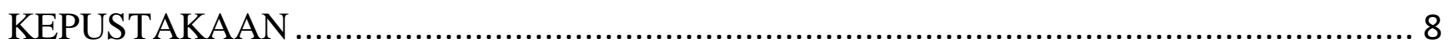




\section{BAB I}

\section{PENDAHULUAN}

\section{A. Latar Belakang}

Menurut Poerwadarminta (dalam Bayardi, 2002:1) Kata wacana berasal dari kata vacana ‘bacaan' dalam bahasa sanskerta. Kata wacana kemudia masuk ke dalam bahasa Jawa Kuno dan bahasa Jawa Baru yaitu wacana atau 'bicara, kata, ucapan'. Kata wacana dalam bahasa Jawa Baru itu kemudian diserap ke dalam bahasa Indonesia menjadi wacana 'ucapan, percakapan, kuliah'. Menurut Bayardi (2002:17) hubungan antar bagian wacana dapat dibedakan menjadi dua jenis, yaitu hubungan bentuk yang disebut kohesi (cohesion) dan hubungan makna atau hubungan semantic yang disebut koherensi (coherence).

Anjani (2013) dalam penelitiannya menyatakan bahwa sebuah wacana dikatakan padu apabila mengandung aspek-aspek kohesif yang mengandung koherensian wacana. Nisa (2011) dalam penelitiannya menyatakan bahwa Terdapat empat jenis sarana kohesi gramatikal dan tiga jenis sarana kohesi leksikal. Eriyanti (2016) dalam penelitiannya menyatakan bahwa koherensi implisit dinyatakan menggunakan penanda penghubung formal (penanda kohesi) pengulangan (reduplikasi), substitusi, penanda hubungan unsur kalimat, koreferensi, dan hubungan leksikal, sedangkan koherensi implisit dapat dipahami melalui inferensi, kesamaan pengetahuan dunia penutur dan mitra tutur, melalui penafsiran lokal, dan implikatur. Kurniyati (2012) Dalam penelitiannya menyatakan bahwa bentuk kesalahan penggunaan alat kohesi yaitu kesalahan konjungsi, kesalahan repetisi, kesalahan subtitusi, kesalahan kolokasi, dan kesalahan konjungsi. Penyebab kesalahan alat koherensi meliputi kesalahan penalaran dan logika berbahasa, generalisasi terlalu luas, dan kesalahan karena hubungan sebab akibat tidak memadai. Itaristanti (2016) dalam penelitiannya menyatakan bahwa kesalahan terbanyak yautu penggunaan unsur konjungsi yang meliputi konjungsi dan, namun, sehingga, dan tetapi. 


\section{B. Rumusan Masalah}

1. Bagaimana analisis kohesi dan koherensi dalam teks cerpen?

2. Bagaimana analisis kohesi dan koherensi dalam teks prosedur?

3. Bagaimana analisis kohesi dan koherensi dalam teks lingkungan?

4. Bagaimana kemungkinan pembelajaran ketiga wacana tersebut di sekolah?

\section{Tujuan Penulisan}

1. Untuk mendeskripsikan analisis kohesi dan koherensi dalam teks cerpen.

2. Untuk mendeskripsikan analisis kohesi dan koherensi dalam teks prosedur.

3. Untuk mendeskripsikan analisis kohesi dan koherensi dalam teks lingkungan.

4. Untuk mendeskripsikan kemungkinan pembelajaran ketiga wacana tersebut di sekolah. 


\section{BAB II}

\section{KAJIAN PUSTAKA}

Kohesi merupakan aspek bentuk yang mengacu kepada aspek formal bahasa yakni bagaimana proposisi-proposisi berhubungan satu sama lainnya untuk membentuk suatu teks (Tarigan, 2009:92). Artinya kohesi merupakan organisasi sintaktik dimana kalimat-kalimat disusun secara terpadu untuk menghasilkan wacana, baik dari segi tingkat gramatikal maupun tingkat leksikal tertentu. Menurut Renkema (2004) koherensi merupakan jalinan antar bagian dalam wacana, jadi koherensi adalah kesinambungan informasi. Dengan kata lain koherensi adalah pemahaman tentang makna yang dimiliki oleh pendengar atau pembaca.

Teks merupakan semua bentuk bahasa, tidak hanya kata-kata yang tertulis, tetapi juga semua ucapan, efek suara, gambar, ekspresi komunikasi dan lainnya. (Kridalaksana, 2008: 204). Tarigan (2009:26) menyatakan bahwa wacana adalah suatu bahasa yang terlengkap dan tertinggi atau terbesar di atas kalimat atau klausa dengan koherensi dan kohesi tinggi yang berkesinambungan yang mempunyai awal dan akhir yang nyata disampaikan secara lisan atau tertulis. 


\section{BAB III}

\section{HASIL DAN PEMBAHASAN}

\section{A. Analisis Teks Cerpen "Si Bangkak" Karya A.A Navis berdasarkan Kohesi dan Koherensi}

1. Kohesi Gramatikal Penunjukan

Penunjukan adalah salah satu koherensi gramatikal yang berupa satuan lingual tertentu yang merujuk satuan lingual yang mendahului atau mengikutinya. Seperti: itu. bukti:

a. Karena tiba-tiba pistol itu meledak ketika lagi dibersihkan dan ketika itu pula istri mayor yang kebetulan lewat di halaman.

b. Sejak itu, bila Mayor Udin asyik main ceki di ruang depan, bila sakit kepala nunung pun datang.

2. Kohesi Gramatikal Pengganti

Pengganti atau penyulihan adalah kohesi gramatikal yang berupa pengganti konstituen tertentu dengan konstituen lain. Seperti: dia, -nya dan mereka. Bukti:

a. Dia tertembak tepat di jantungnya.

b. "ya tolong pijat cepat" katanya sambil memberikan botol balsam.

3. Koherensi Narasi Temporal. Bukti:

Setelah kening dan tengkuknya dipijat, rasa sakit kepala nunung memang dirasanya berkurang. Lalu Si Bangkak disuruhnya memijat punggungnyajuga, seperti biasa yang dilakukan kepada Mayor Udin.

\section{B. Analisis Teks Prosedur "Cara Memasak Mie Goreng Instan" berdasarkan Kohesi dan Koherensi}

1. Kohesi Gramatikal Penunjuk Anaforis. Bukti:

a. Setelah itu, masukan bumbu-bumbu ke dalam piring atau mangkuk. 
2. Koherensi Prosedural

Koherensi procedural yaitu kehorensi berupa tahap terjadinya peristiwa. Bukti:

- Rebus dua gelas air ke dalam panci kemudian masukan mie instan setelah air mendidih.

- Setelah itu, masukan bumbu-bumbu ke dalam piring atau mangkuk.

- Setelah matang, tiriskan mie instan lalu c

- campur mie bersama bumbu.

- Mie goring instan siap untuk dikonsumsi

\section{Analisis Teks Wacana Lingkungan "Sampah Rumah Tangga" berdasarkan Kohesi dan Koherensi}

1. Kohesi Gramatikal Penunjuk Anaforis. Bukti:

Karena itu, sudah sepatutnya pengatahuan menganai pengelolahan sampah rumah tangga pada tiap keluarga harus segera ditanamkan.

2. Kohesi Pengganti. Buktinya:

Misalnya, mengurangi pembelian air minum kemasan dan menggantinya dengan membawa air dari rumah.

3. Koherensi Eksposisi Kausalitas

Rumah tangga adalah salah satu penghasilan sampah anorganik yang cukup tinggi. oleh karena itu, pengelolaan sampah secara mandiri atau individu dalam kehidupan keluarga sangat penting. Yang salah satunya bisa dilakukan dengan cara di atas yaitu melalui 3R dan melalui kesadaran individu tiap keluarga itulah, perlahan akan tumbuh kesadaran individu dengan lingkungan sosialnya. Akhirnya akan tercipta lingkungan bersih dari sampah. 


\section{Deskripsi Kemungkinan Pembelajaran Ketiga Wacana Tersebut di Sekolah}

Pembelajaran bahasa Indonesia berbasis teks ialah peroses blajar bahasa Indonesia yang dilakukan oleh siswa yang berawal dari pemahaman teks sehingga mampu membuat teks. Pembelajaran berbasis teks merupakan ciri khas dari pembelajaran bahasa Indonesia yang tertera pada kurikulum 2013 (Isodarus, 2017). Pada mata pelajaran bahasa Indonesia teks bukanlah suatu hal yang asing. Teks sudah menjadi bagian dari komponen pembelajaran di sekolah. Dalam pembalajaran bahasa tentunya tidak lepas dari teks (Agustina, 2017). Teks cerpen, teks prosedur dan teks lingkungan memungkinkan untuk dijadikan materi pembalajaran bahasa Indonesia di sekolah. Hal tersebut dikarenakan selain ketiga teks telah memiliki kohesi dan koherensi, ketiga teks tersebut dapat menjadi media untuk mengembangkan pola piker siswa yang berbeda satu sama lain. Semakin siswa menguasai banyak teks dalam pembelajaran maka semakin bertambahlah ilmu pengetahuan dan pola piker siswa semakin berkembang. Oleh karena itu, teks tersebut memiliki kemungkinan yang besar digunakan untuk pembelajaran. 


\section{BAB IV \\ PENUTUP}

\section{A. Simpulan}

Kata wacana berasal dari kata vacana 'bacaan' dalam bahasa sanskerta. Kata wacana kemudia masuk ke dalam bahasa Jawa Kuno dan bahasa Jawa Baru yaitu wacana atau 'bicara, kata, ucapan'. Kata wacana dalam bahasa Jawa Baru itu kemudian diserap ke dalam bahasa Indonesia menjadi wacana 'ucapan, percakapan, kuliah'. hubungan antar bagian wacana dapat dibedakan menjadi dua jenis, yaitu hubungan bentuk yang disebut kohesi (cohesion) dan hubungan makna atau hubungan semantic yang disebut koherensi (coherence).

Pada teks cerpen yang berjudul "Si Bangkak" terdapat kohesi Kohesi Gramatikal Penunjukan, Kohesi Gramatikal Pengganti, dan terdapat Koherensi Narasi Temporal.

Pada teks prosedur yang berjudul" Cara Memasak Mie Goreng Instan" terdapat Kohesi Gramatikal Penunjuk Anaforis dan Koherensi Prosedural.

Pada teks wacana lingkungan yang berjudul "Sampah Rumah Tangga" terdapat Kohesi Gramatikal Penunjuk Anaforis, Kohesi Pengganti, dan terdapat Koherensi Eksposisi Kausalitas.

Ketiga teks tersebut baik untuk dijadikan materi pembelajaran disekolah. Hal tersebut karena ketiga teks tesebut telah memiliki kohesi dan koherensi yang bisa membantu proses pembalajaran bahasa Indonesia di sekolah.

\section{B. Saran}

Makalah ini banyak memiliki kekurangan, oleh karena itu kritikan dan saran dari pembaca sangat penulis harapkan. 


\section{KEPUSTAKAAN}

Anajani, (2013). Kohesi dan Koherensi Wacana stand up comedy Prancis dan Indonesia. Jurnal Kawistara, 22 (3), p 298-299.

Agustina, E. S. (2017). Pembelajaran Bahasa Indonesia Berbasis Teks: Representasi Kurikulum 2013. AKSARA Jurnal Bahasa dan Sastra, 18(1), p 84-99.

Arviyana, M., Syahrul., dan Tressyalina. (2017). Pengaruh Model Discovery Learning Berbantuan Media Audiovisual terhadap Keterampilan Menulis Teks Prosedur Siswa Kelas VII SMP Negeri 12 Padang. Jurnal Pendidikan Bahasa dan Sastra Indonesia, Vol 6(2), p 183-191.

Bayardi, P. (2002). Dasar-dasar Analisis Wacana dalam Ilmu Bahasa. Jogjakarta: Pustaka Gondho Suli.

Eriyanti, R. W. (2016). Koherensi Pernyataan Guru pada Pembelajaran. Jurnal Keilmuan Bahasa. 2(1), p 77-89.

Fitrianita, D., Syahrul. R., dan Tressyalina. (2017). Korelasi Keterampilan Memahami Teks Deskripsi dengan Keterampilan Teks Deskripsi Siswa Kelas VII SMP Negeri 15 Padang. Jurnal Pendidikan Bahasa dan Sastra Indonesia, 6(2), p 102-108

Isodarus, P. B. (2017). Pembelajaran Bahasa Indonesia Berbasis Teks. Jurnal Ilmiah Kebudayaan SISTESIS, 11(1), p 88-95.

Itaristanti. (2016). Aspek Kohesi dan Koherensi dalam Penulisan Karangan Deskripsi yang Disusun oleh Pembelajar BIPA. Jurnal Indonesian Language Education and Literature. 2(1), p 88-98.

Jaya, S., Syahrul, R., dan Ermanto. (2013). Peningkatan Keterampilan Menulis Puisi Melalui Media Gambar Siswa Kelas X.I SMA Negeri 2 Kota Sungai Penuh. Jurnal Bahasa, Sastra dan Pembelajaran, 1(2), p 88-95.

Kridalaksana, H. (2008). Kamus Linguistik. Jakarta: Gramedia Pustaka Utama.

Kurniyati, D. D. (2012). Analisis Kesalahan Kohesi dan Koherensi Paragraf pada Karangan Siswa Kelas X SMA Negeri 3 Temanggung. Skripsi: Universitas Negeri Yogyakarta. 
Nisa, H. U. (2011). Kohesi dan Koherensi Antar Kalimat dalam Wacana Berita di Majalah Penjebar Semangat. Skripsi: Universitas Negeri Semarang.

Putri, N., Syahrul, R., dan Afnita. (2018). Pengaruh Penggunaan Model Discovery Learning Berbantuan Media Audiovidual terhadap Keterampilan Teks Biografi Siswa Kelas X SMA Negeri 12 Padang. Jurnal Pendidikan Bahasa dan Sastra Indonesia, 7(3), p 192-198.

Renkema, J. (2004). Introducion to Discourse Studies. Amsterdam: John Benjamins.

Subagyo, B. S. (2012). Analisis Kohesi dan Koherensi Rubrik Tajuk Rencana pasa Surat Kabar Solopos dan Relevansinya sebagai Bahan Ajar Pembelajaran Bahasa Indonesia pada SMA. Skripsi: Universitas Sebelas Maret.

Tarigan, H. G. (1987). Pengajaran Wacana. Bandung: Angkasa. 